\title{
Long-term agricultural activity affects anthropogenic soil on the Chinese Loess Plateau
}

\author{
LI Xiaoyun ${ }^{1,2^{*}}$, WANG Yiquan ${ }^{3}$, Mark E REYNOLDS ${ }^{4}$, LI Xiaoping ${ }^{1,2}$, LU Xinwei $^{1}$ \\ ${ }^{1}$ School of Geography and Tourism, Shaanxi Normal University, Xi'an 710119, China; \\ ${ }^{2}$ SNNU-JSU Joint Research Center for Nano-environment Science and Health, Xi'an 710119, China; \\ ${ }^{3}$ College of Resources and Environment, Northwest A\&F University, Yangling 712100, China; \\ ${ }^{4}$ Stockbridge School of Agriculture, University of Massachusetts, Massachusetts 01003, USA
}

\begin{abstract}
Anthropogenic activities largely influence the soil quality of agricultural fields and the composition of soil. Samples of typical anthropogenic Loutu soil in the Guanzhong area of the Loess Plateau, Shaanxi Province, China were collected and measured for soil compaction, bulk density, total organic carbon (TOC), active organic carbon (AOC), and soil enzyme activities to investigate spatial variations in soil quality. The results indicate that soil compaction and bulk density increased with increasing distance from the farm village, whereas soil TOC, AOC, and soil enzyme activities firstly increased and subsequently decreased with increasing distance from the farm village. All of the tested parameters presented clear concentric distribution. Vertically, soil compaction and bulk density in the topsoil were lower than those in the subsoil, but all other tested parameters in the topsoil were significantly higher than those in the subsoil. In addition, there was a significant positive correlation between organic carbon content and enzyme activities, confirming that the spatial distribution of Loutu soil characteristics has been affected by long-term anthropogenic activities to some extent. The results of this study imply that the use of farmyard manure and appropriate deep plowing are important and effective ways to maintain and improve soil quality.
\end{abstract}

Keywords: anthropogenic soil; spatial variation; organic carbon; enzyme activity; soil quality

Citation: LI Xiaoyun, WANG Yiquan, Mark E REYNOLDS, LI Xiaoping, LU Xinwei. 2017. Long-term agricultural activity affects anthropogenic soil on the Chinese Loess Plateau. Journal of Arid Land, 9(5): 678-687. doi: $10.1007 / \mathrm{s} 40333-017-0026-2$

\section{Introduction}

The term anthropogenic soil specifically refers to soil that develops in any parent material or soil via long-term anthropogenic influences (Liang et al., 2003; Berg and Laskowski, 2005). Loutu soil, a typical Earth-Cumuli-Orthic Anthrosol, is widely distributed in the Guanzhong area of Shaanxi Province. It is one of the Hapli-Ustic Argosols developed from the Malan Loess parent material and has been modified by 4000 years of farmyard manure application (mainly a mixture of soil and livestock manure) and tillage ( $\mathrm{Li}$ et al., 2010; Sun et al., 2013). The soil is therefore considered as an important part of the cradle of Chinese civilization (Zhu, 1989; Wang et al., 2010). In ancient times, due to limited transport options and an insufficient quantity of organic fertilizers, manure was always applied based on proximity to the farming village. Thus, farmland either near or far from villages showed obvious differences in how much manure they had received and for how long it had been applied. Due to this long-term soil management and

*Corresponding author: LI Xiaoyun (E-mail: lixiaoyun518@163.com; lxy518@snnu.edu.cn)

Received 2016-09-21; revised 2017-06-20; accepted 2017-06-29

(C) Xinjiang Institute of Ecology and Geography, Chinese Academy of Sciences, Science Press and Springer-Verlag GmbH Germany 2017 
fertilization practice, the soil profile and soil fertility levels surrounding a village have concentric-circle distributions for a given soil characteristic. This obvious distribution characteristic is the result of pedogenic and evolutionary processes, but is also a result of the integrated impact of a long history of anthropogenic activities. Therefore, the development and evolution of Loutu soil embodies the historical imprint of human agricultural production and cultivation.

The effects of human activities on soil evolution have drawn considerable scientific attentions throughout the world. Yaalon and Yaron (1966) referred the impact of human actions on agricultural soils as "metapedogenesis". Tang et al. (2003) reported that human activities have prominent effects on the quality of cultivated land. Dudal et al. (2002) proposed that the influence of humans on soil formation is more profound and extensive than originally believed. They suggest that it is imperative that this influence should be explicitly recognized as an independent soil-forming factor. Tobiašová et al. (2011) noted that in agro-ecosystems, humans change the soil structure via the burial of various crop residues, organic fertilizer application, cultivation, and land use. However, most researchers have only focused on macroscopic changes in soil, such as soil erosion (Fu et al., 2009), soil nutrition (Mazzoncini et al., 2011; Zhou et al., 2015), soil pollution (Gómez-Sagasti et al., 2012; Szolnoki et al., 2013; Burges et al., 2015), and soil salinization (Masto et al., 2008; Al-Hamaiedeh and Bino, 2010; Rezapoụr and Samadi, 2012; Siggins et al., 2016). Researchers have generally neglected the intrinsic evolution of soil quality as a result of long-term human agricultural activities.

In this paper, farmland around Duzai Village in the Guanzhong area of the Chinese Loess Plateau was investigated. This area has been affected by/human agricultural production for 4000 years. The objective of this experiment was to uncover the effects of long-term human agricultural activities on the spatial variability of soil quality and various biological properties with a hope that our knowledge of pedology can be expended.

\section{Materials and methods}

\subsection{Study area}

This study area is located in Duzai Village $\left(34^{\circ} 16^{\prime} \mathrm{N}, 108^{\circ} 04^{\prime} \mathrm{E}\right)$ in the semi-arid area of Northwest China. It has an average annual precipitation of $437 \mathrm{~mm}$ and an annual mean temperature of $12.9^{\circ} \mathrm{C}$. Generally, the thickness of the soil in this region is $40-60 \mathrm{~cm}$. With increasing distance from the village, the thickness gradually declines. For 4000 years, this region has maintained a relatively high level of agricultural production. The spatial variability of the soil quality in the area shows a typical pattern and the pattern was formed by the long-term anthropogenic application of manure and tillage (Zhang, 1987). In recent decades, wheat-maize double cropping has been the dominant agricultural production system in this region. Thirty years ago, the average amount of manure applied was about $50 \times 10^{3} \mathrm{~kg} / \mathrm{hm}^{2}$ (being equal to organic matter about 4000 $\mathrm{kg} / \mathrm{hm}^{2}$ ). Since 2000, chemical fertilizer has been gradually accepted by farmers and become the main fertilizer. The main cultivation method is rotary tillage.

\subsection{Experimental design}

In the autumn of 2014, after maize was harvested but before wheat was planted, three radial lines originating from Duzai Village (as the center) were established. Using a grid method, eight plots (50 $\mathrm{m} \times 50 \mathrm{~m}$ ) were mapped out along each radial line. Three sub-samples were collected randomly from each plot using a soil auger at depths ranging from 0-20 cm, and another three sub-samples were collected at depths ranging from $20-40 \mathrm{~cm}$. Thus, a total of 144 samples (8 plots $\times 3$ sub-samples in each plot $\times 3$ lines $\times 2$ layers) were collected. Soil compactness and soil bulk density (its stable bulk density) were tested in three spots (at the same depth) at three layers $(0-10,10-20$ and 20-30 cm) in each plot using a soil compaction meter (Field ScoutTM SC900, Spectrum Technologies Inc., USA) and a core sampler, respectively.

Each soil sample was brought back to lab and separated into two parts after being sieved through a stainless steel 2-mm mesh screen. One part was air-dried and stored in a polyethylene zipper bag 
at room temperature for measurements of the soil physical-chemical properties. The other part was kept at field moisture in a refrigerator at $4^{\circ} \mathrm{C}$ and the enzymatic activities were determined within 2 weeks after sampling.

\subsection{Laboratory analyses}

The total organic carbon (TOC) content was determined by a modified Walkley-Black method (Jackson, 1967) $-\mathrm{K}_{2} \mathrm{Cr}_{2} \mathrm{O}_{7}$ volumetric method with an external heating procedure (adding $\mathrm{Ag}_{2} \mathrm{SO}_{4}$ to eliminate the effect of $\mathrm{Cl}^{-}$). The excess of chromate left after $\mathrm{C}$ oxidation is titrated with standard ferrous sulfate solution instead of ferrous ammonium sulfate to avoid contamination due to $\mathrm{NH}_{4}{ }^{+}$. The active organic carbon (AOC) content was measured according to the $\mathrm{KMnO}_{4}$ oxidation method (with the concentration of $\mathrm{KMnO}_{4}$ at $333 \mathrm{mmol} / \mathrm{L}$ ) using a UV-VIS spectrophotometer (Agilent 8453) at $565 \mathrm{~nm}$ (Blair and Lefroy, 1995).

Urease activity was determined with $\mathrm{C}_{6} \mathrm{H}_{5} \mathrm{ONa}-\mathrm{NaOCl}$ colorimetric method (Tabatabai and Bremner, 1972), and the released ammonium was colorimetrically determined at $578 \mathrm{~nm}$ using indophenol reagent. Alkaline phosphatase activity was analyzed using the $\mathrm{C}_{6} \mathrm{H}_{5} \mathrm{Na}_{2} \mathrm{PO}_{4}$ colorimetric method under $\mathrm{pH} 9.8$ (Tabatabai and Bremner, 1969) and determined colorimetrically at $660 \mathrm{~nm}$. Catalase activity was measured according to the $\mathrm{KMnO}_{4}(0.02 \mathrm{~mol} / \mathrm{L})$ titration method (Zhou, 1987).

All treatments and measurements were run in triplicate, and the average was recorded. Selected properties of the tested soil are listed in Table 1.

Table 1 Selected properties of the tested soil

\begin{tabular}{|c|c|c|c|c|c|c|c|}
\hline \multirow{2}{*}{$\begin{array}{l}\text { Soil depth } \\
\quad(\mathrm{cm})\end{array}$} & \multicolumn{2}{|c|}{ Fraction of particles (\%) } & \multirow{2}{*}{ Soil texture } & \multirow{2}{*}{$\begin{array}{cc}\begin{array}{c}\text { Soil bulk } \\
\text { density } \\
\left(\mathrm{g} / \mathrm{cm}^{3}\right)\end{array} & \begin{array}{c}\text { Compaction } \\
(\mathrm{KPa})\end{array}\end{array}$} & \multirow{2}{*}{$\begin{array}{c}\text { TOC } \\
(\mathrm{g} / \mathrm{kg})\end{array}$} & \multirow{2}{*}{$\begin{array}{l}\text { AOC } \\
(\mathrm{g} / \mathrm{kg})\end{array}$} & \multirow{2}{*}{$\mathrm{pH}$} \\
\hline & $1-0.01 \mathrm{~mm}$ & $<0.01 \mathrm{~mm}$ & & & & & \\
\hline $0-20$ & 41.34 & 58.66 & 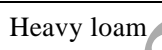 & $733 \pm 50.82$ & $10.74 \pm 1.08$ & $4.67 \pm 0.61$ & 8.22 \\
\hline $20-40$ & 42.62 & 57.38 & Heavy loam & $2435 \pm 348.75$ & $6.24 \pm 0.59$ & $2.36 \pm 0.46$ & 8.14 \\
\hline
\end{tabular}

Note: TOC, total organic carbon; AOC, active organic carbon.

\subsection{Data analysis}

All data were analyzed using-Microsoft Excel 2010 and DPS v7.5. Spatial contour maps of the selected physical properties of the soil were made using Surfer v9.0 to indicate the influence of modern soil management and historical soil management practices on Loutu soil quality based on analyses of the layers at $0-20$ and $20-40 \mathrm{~cm}$ soils. All significant effects were determined at the 0.05 probability level.

\section{Results and discussion}

\subsection{Effects of long-term agricultural activity on the spatial variability of the soil physical properties}

Soil bulk density and compactness are two important physical indicators for soil quality assessment, and they can also reflect the fatigue of soil. Soil compaction has recently drawn considerable attention as a critical indicator of soil quality degradation (Batey, 2009; Nawaz et al., 2013; Chamen et al., 2015). This is particularly the case for the subsoil compaction (Berisso et al., 2012; Etana et al., 2013) due to its non-ameliorated symptoms via cultivation (Jones et al., 2003; Gregory et al., 2007). From Figures 1a-c, it can be clearly seen that soil compaction of the tested area gradually increased in the $0-10,10-20$ and $20-30 \mathrm{~cm}$ soil layers from the village to the ends of the radial lines. However, the variability of soil compaction in the topsoil was smaller than that in the subsoil. Thus, it is evident that deep soil cultivation was gradually reduced and less manure was applied as the distance from the village increased. In the same soil profile, soil compaction in the 20-30 cm layer was almost twice that in the 10-20 cm layer and almost ten times greater than that in the $0-10 \mathrm{~cm}$ layer, demonstrating that the soil compaction problem in this area is extremely severe in the subsoil. Subsoil compaction signifies that the layer of topsoil with conditions suitable for plant growth have become thinner. Soil compaction can be resulted from 
the combined effects of long-term human agricultural practices, such as reduced use of organic matter, increased use of chemical fertilizers and persistent plowing at the same depth for many years. In the Guanzhong area, soil compaction had a concentric spatial variability in the horizontal direction from the village to the ends of radial lines. This was caused by thousands of years of manure application and the manure application has been inversely proportional to the proximity to the village. Moreover, the vertical variation of soil compaction was most likely resulted from a long period of rotary tillage. Over the past four decades, deep plow cultivation has been seldom used by farmers to loosen the soil and the compaction of deep part of the soil was thus resulted (Jiao et al., 2009). The subsoil compaction can directly affect soil permeability, soil aeration and the development of crop root (Gary and Patrick, 2006; Grzesiak, 2009; Muhammad et al., 2012; Nawaz et al., 2013). A reduced root network is then likely to affect a plant's ability to take up water and nutrients (Mooney and Nipattasuk, 2003; Kristoffersen and Riley, 2005; Gregorich et al., 2014).
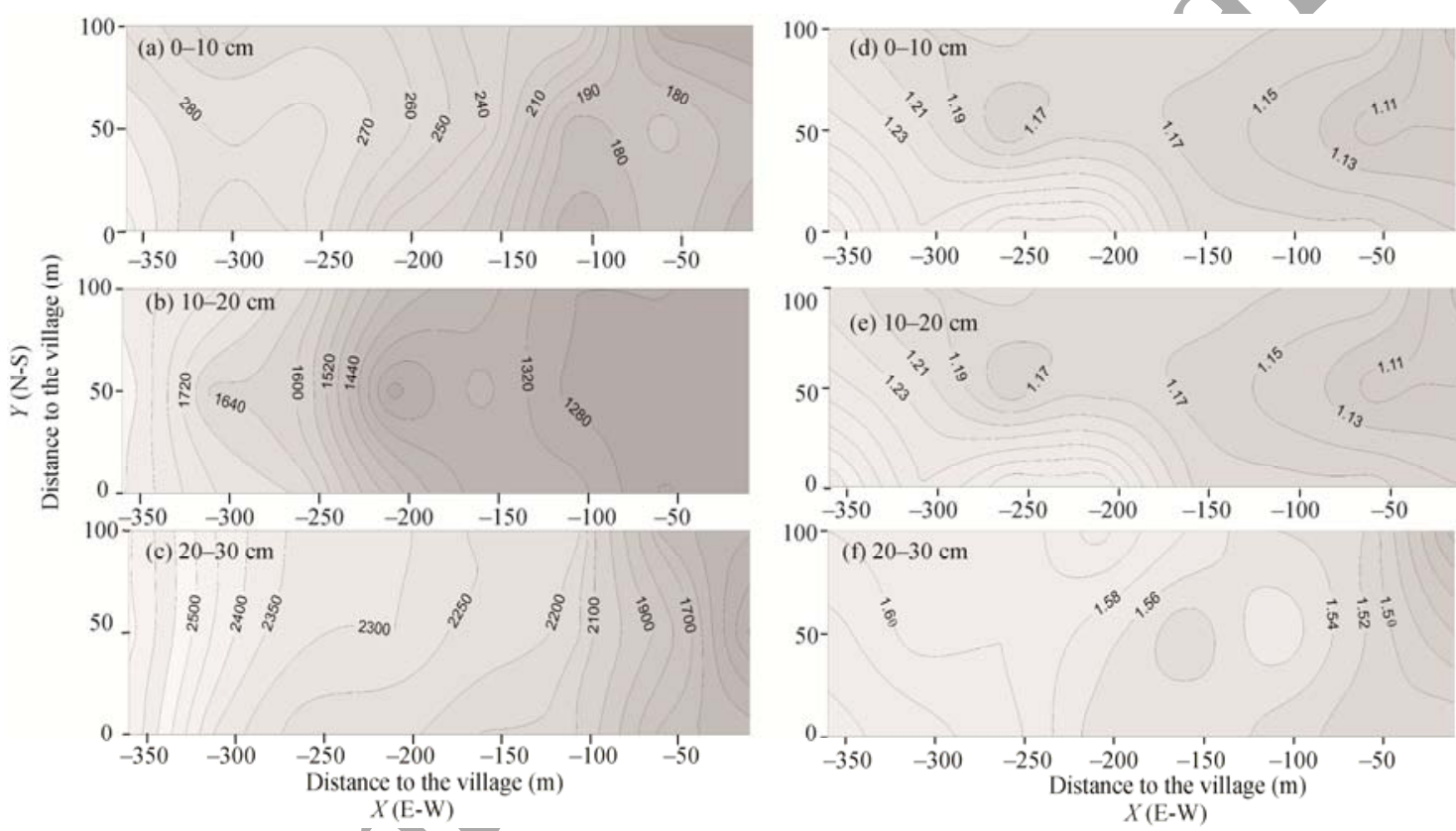

Fig. 1 Spatial contour maps of soil compaction $(K P a, a-c)$ and soil bulk density $\left(g / \mathrm{cm}^{3}, d-f\right)$ in the $0-10,10-20$ and $20-30 \mathrm{~cm}$ soil layers with distance to the village

The compaction is often accompanied by soil bulk density increase (Twnm and Nii-Annang, 2015). Thus, bulk density of the tested area was also measured. From Figures 1d-f, it can be seen that the spatial variation of the soil bulk density is similar to that in the soil compactness. The average bulk densities in the $0-10,10-20$ and 20-30 cm layers were $1.19,1.48$ and $1.56 \mathrm{~g} / \mathrm{cm}^{3}$, respectively. As compared with soil compactness, soil bulk density of the subsoil was also apparently higher than that of the topsoil, again showing that both degrees of soil compaction and the values of bulk density increase with increasing the soil depth. This is mainly because of less soil tillage and manure application with increasing soil depth.

\subsection{Effects of long-term agricultural activity on the spatial variation of TOC and AOC contents}

As the most important component of soil fertility, soil organic matter is closely associated with a wide arrange of physical-chemical and biological properties of the soil, and therefore plays a key role in soil forming processes and functioning (Smith et al., 2000; Schroth et al., 2003). Hence, soil organic matter can also be used as an indicator for soil fatigue assessment. Soil organic matter is influenced by many factors, such as soil parental material, climatic conditions, land use, and managements including tillage and fertilization (Ogle et al., 2005; Bhattacharyya et al., 2007; 
Verma et al., 2010; Zhang et al., 2012, 2013). Different fertilization methods and farm management practices can directly affect the spatial variations of soil organic matter (Ogle et al., 2003; Liang et al., 2012). Soil organic carbon activity (OCA) is thought to be a sensitive indicator of early changes in soil quality under different human management practices because it can reflect micro changes in soil quality more sensitively than total organic carbon (TOC) (Zhang and Sui, 2011).

In this study, both TOC and AOC contents in 0-20 and 20-40 cm soil layers were measured (Fig. 2), and the results indicated that TOC and AOC contents first gradually increased from the village to about $100 \mathrm{~m}$ away from the village in both layers: their highest values were 20.75 and $9.64 \mathrm{~g} / \mathrm{kg}$ in the $0-20 \mathrm{~cm}$ layer and 12.17 and $5.42 \mathrm{~g} / \mathrm{kg}$ in the $20-40 \mathrm{~cm}$ layer, respectively. Then, from $100 \mathrm{~m}$ away from the village to the ends of the tested radial lines, these values gradually declined. This apparent concentric distribution characteristic revealed that the significant impact of manure application and agricultural management. Historically, due to poor transport conditions and limited amount of organic fertilizers, manure was always applied based on proximity to the region. In other words, more manure was applied within about $100 \mathrm{~m}$ away from the village. Farther away from the village, the less the amount and frequency of organic fertilizers were applied. Due to this long-term soil management and manure application practice, the soil profile and soil fertility levels surrounding a village have concentric-circle distributions for a given soil characteristic. This obvious distribution characteristic is the result of pedogenic and evolutionary processes. But, it is also a result of the integrated impact of a long history of anthropogenic activities.
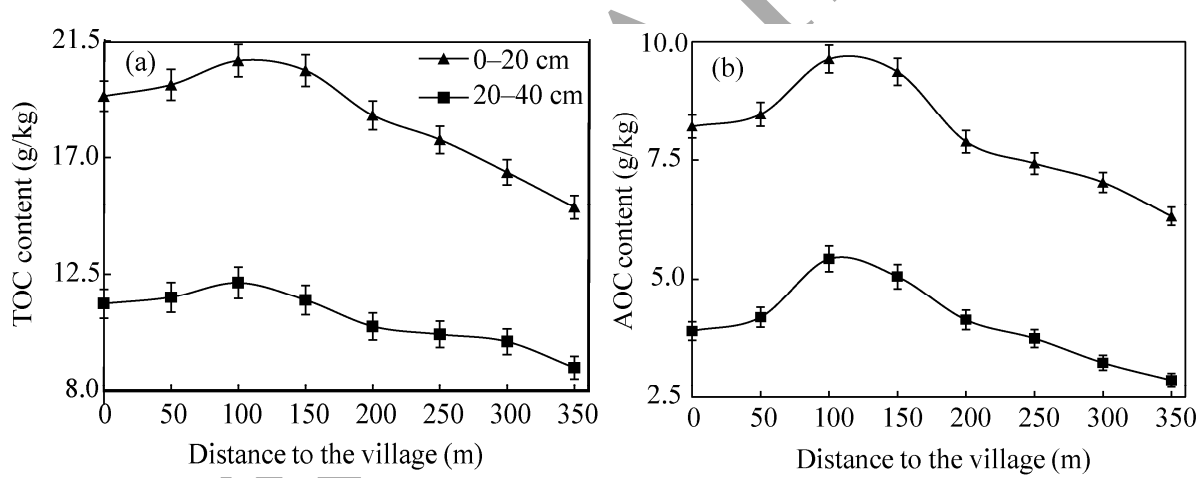

Fig. 2 Changes in total organic carbon (TOC, a) and active organic carbon (AOC, b) contents in the 0-20 and 20-40 cm soil layers with distance to the village, bars mean standard errors.

Soil OCA, a newly-proposed index to measure the availability of organic carbon, is defined as follows: OCA=AOC/(TOC-AOC). From Figure 3, it can be seen that OCA values at 100 and 150 $\mathrm{m}$ dístances were significantly higher than those at other distances in both layers. In the $20-40 \mathrm{~cm}$ layer, OCA values reached approximately 0.8 at 100 and $150 \mathrm{~m}$ distances, whereas these values were only 0.5 at the ends of the radial lines. These results indicated that before the modern agriculture, the farmland that 100-150 m away from the village received the highest amount and the longest period of manure application. In addition, OCA values in the $0-20 \mathrm{~cm}$ layer fluctuated between 0.7 and 0.9 over the entire experimental area, illustrating that the proportions for soil organic matter composition tended to be consistent. This is mainly due to reduced manure application and the increased use of inorganic fertilizer, the latter (recent use of inorganic fertilizer) being not limited by distance. Some researches (Mitchell et al., 1991; Schjonning et al., 1994; Berzsenyi et al., 2000) showed that the long-term applications of inorganic fertilizers could increase soil organic carbon content by increasing crop yields and thereby increasing the return of crop residues to the soil. Since most crop residues are easily decomposed by microorganisms, this consequently increases the AOC content of the soil. Therefore, changes in OCA values in the topsoil from the village center to the ends of the radial lines tended to be small. 


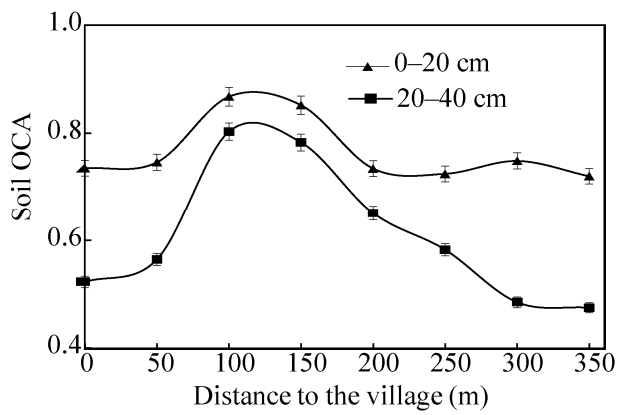

Fig. 3 Changes of soil organic carbon activity (OCA) in the 0-20 and 20-40 cm layers with distance to the village, bars mean standard errors.

\subsection{Effects of long-term agricultural activity on the spatial variability of soil enzyme activities}

Soil enzymes are not only an indirect reflection of soil microbial activity but also an indicator of overall soil fertility and soil quality (Franco et al., 2004; Gianfreda et al., 2005; Li et al., 2005; Shen et al., 2005; Labud et al., 2007). Urease, alkaline phosphatase, and catalase are abundant in soil. Urease is related to the soil's nitrogen supply capacity, alkaline phosphatase can enhance the decomposition of phosphates to improve crop absorption. Catalase is an intracellular enzyme involved in microbial oxidoreductase metabolism (García-Gil et al., 2000), a process that efficiently catalyzes hydrogen peroxide-a crop toxin. Therefore, these three soil enzymes were selected to examine the relationships between long-term human activities and soil enzyme activities.

In the horizontal direction, urease, alkaline phosphatase, and catalase activities displayed marked differences in both layers at different distances from the village (Fig. 4), and they followed the same trend as TOC and AOC. All three enzymes showed the highest bioactivities at about $100 \mathrm{~m}$ away from the village in both soil layers (0-20 and 20-40 cm), being in accordance with results from previous studies (Chang et al., 2007; Mohammadi, 2012). The formation of this pattern is mainly due to high frequency and amount of manure application at this distance away from the village. In the vertical direction, three enzymatic activities in the topsoil were higher than those in the subsoil as a whole. To be specific, nearby the village, the enzymatic activities presented significant differences between the 0-20 and the 20-40 cm layers. However, beyond $100 \mathrm{~m}$, the difference of the activities in both layers began to diminish. For urease and alkaline phosphatase, their activities decreased more sharply in the $0-20 \mathrm{~cm}$ soil layer than in the 20-40 $\mathrm{cm}$ soil layer. Thus, the activity values of urease and alkaline phosphatase became similar at the ends of the radial lines, revealing that, taking the village as the center, the radius of organic fertilizer application in this region was approximately $350 \mathrm{~m}$.

Throughout history, agricultural production in this area mainly depended on soil natural fertility and limited organic fertilizer application. The farther away from the village is, the less human intervention and manure application will be. Thus, soil enzyme activities, historically, were closer to their natural state. However, in recent decades, with the increasing use of chemical fertilizers and serious soil degradation associated with intensive farming, agricultural production in this area has begun to depend on the amount of inorganic fertilizer used. Some studies (Marinari et al., 2000; Li et al., 2012; Mohammadi, 2012) have reported that although both organic fertilizer and inorganic fertilizer could increase soil enzyme activities, and enzyme activities were generally higher in soils treated with organic fertilizers than in those treated with chemical fertilizers. Additionally, the excessive application of inorganic fertilizers can, to a certain extent, reduce soil enzyme activities because enzymatic reactions are restrained by chemical fertilizers (Zhang et al., 2010). Hence, being farther away from the village, enzyme activities in the topsoil were similar to those in the subsoil, demonstrating that less human manure and more chemical fertilizer were applied. 

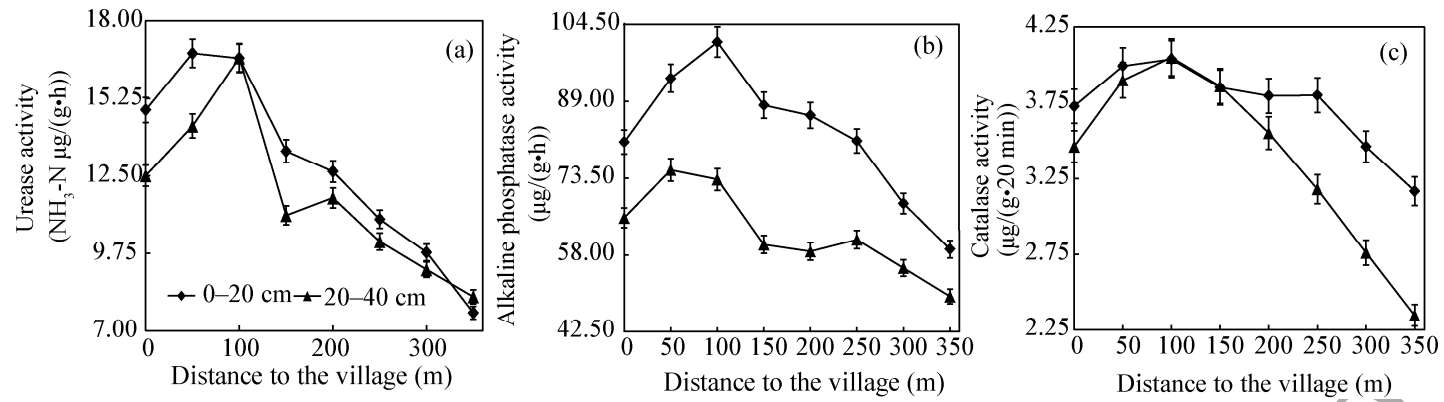

Fig. 4 Variations in enzymatic activities in the 0-20 and 20-40 cm soil layers with distance to the village, bars mean standard errors.

\subsection{Correlation analysis}

Soil organic matter content was a result of the balance between organic matter formation and decomposition in the soil. In particular, soil enzyme activities determine the strength and direction of soil organic matter transformation. Some researchers (Calderon et al., 2000; Drijber et al., 2000; Colombo et al., 2002; Nannipieri et al., 2002) considered soil enzyme activities as suitable indicators of soil quality because (1) they are a measure of soil microbial activity level and therefore are strictly related to nutrient cycles and transformations, (2) they rapidly respond to the changes caused by both natural and anthropogenic factors, and (3) they are easy to measure. Thus, this study also analyzed the relationship between soil organic carbon content and enzymatic activities.

Whether in topsoil or subsoil, both TOC and AOC contents showed significant positive correlations with three soil enzyme activities (see Table 2). The correlation coefficients between organic carbon content (both TOC and AOC) and urease and alkaline phosphatase activities in the topsoil were higher than those in the subsoil, whereas those for catalase in the topsoil were lower than those in the subsoil. It showed that human disturbance has affected the soil organic carbon content and further influenced soil enzyme distributions. Additionally, all of the correlation coefficients for the three enzyme activities with TOC content were higher than those with AOC content. This is mainly because soil is a carbon-limited environment, and the AOC content is contingent on the TOC content and the labile carbon fraction. Some previous researches also considered that/enzyme activities were more strongly related to soil total organic matter content than to microbial biomass carbon content because soil colloids have a protective effect on soil enzymes (Banerjee and Burton, 1998; Bergstrom et al., 2000).

Table 2 Correlation analysis between soil organic carbon content and enzyme activities

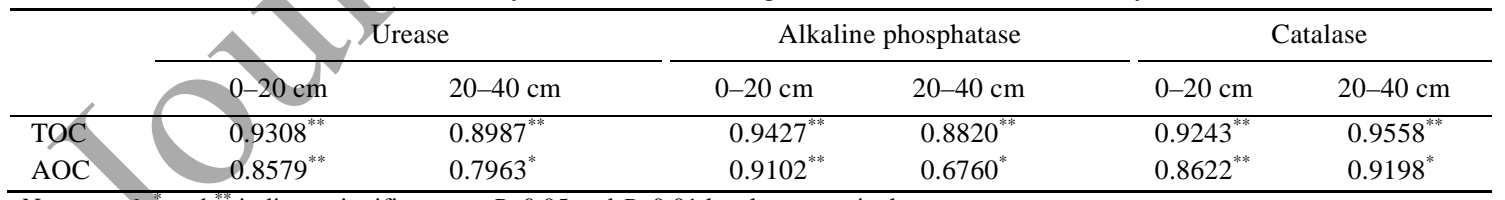

Notes: $n=6$, ${ }^{*}$ and ${ }^{* *}$ indicate significance at $P<0.05$ and $P<0.01$ levels, respectively.

\section{Conclusions}

The results from this study showed that all the tested parameters presented obvious concentric distribution pattrerns along the horizontal directions, which fully reflected 4000 years of conventional farming habits. Vertically, soil TOC and AOC contents and enzyme activities in the topsoil were higher than those in the subsoil, but soil compaction and bulk density in the topsoil were lower than those in the subsoil. Loutu soil in this region presented an apparent problem with more compacted subsoil and thinned topsoil (i.e., plough layer). These signs reflected that long-term unreasonable farming and excessive fertilization application have seriously degraded the quality of local soil. We suggest that some preventive measures, such as adding more organic materials, reasonable use of chemical fertilizer, employing appropriate deep ploughing and 
rational crop rotation, planting leguminous plants, and using biochar are needed for Loutu soil to reduce its further degradation and improve its physical-chemical and biological properties. In conclusion, farmland soil quality in this area is significantly affected by human activities. Under the influence of long-term human factors, some physical-chemical and biological properties of local soil exhibit special spatial patterns.

\section{Acknowledgements}

This work was supported by the National Natural Science Foundation of China (41471420), the Natural Science Foundation of Shaanxi Province (2016JQ4016), the Fundamental Research Funds for the Central University (GK201603076, GK201601009, GK201701010), and the Youth Innovation Team Project in the Tourism and Environment College of Shaanxi Normal University. Finally, we would like to thank Prof. XING Baoshan, University of Massachusetts-Amherst for editing the final version of this paper.

\section{References}

Al-Hamaiedeh H, Bino M. 2010. Effect of treated grey water reuse in irrigation on soil and plants. Desalination, 256(1-3): 115-119.

Batey T. 2009. Soil compaction and soil management-a review. Soil Use and Management, 25(4): 335-345.

Berg B, Laskowski R. 2005. Anthropogenic impacts on litter decomposition and soil organic matter. Advances in Ecological Research, 38: 263-290.

Bergstrom D W, Monreal A D, Tomlin C M, et al. 2000. Interpretation of soil enzyme activities in a comparison of tillage practices along a topographic and textural gradient. Canadian Journal of Soil Science, 80(1): 71-79.

Berisso F E, Schjønning P, Keller T, et al. 2012. Persistent effects of subsoil compaction on pore size distribution and gas transport in a loamy soil. Soil and Tillage Research, 122: 42-51.

Berzsenyi Z, Györffy B, Lap D Q. 2000. Effect of crop rotation and fertilisation on maize and wheat yields and yield stability in a long-term experiment. European Journal of Agronomy, 13(2-3): 225-244.

Bhattacharyya R, Chandra S, Singh R D, et al. 2007. Long-term farmyard manure application effects on properties of a silty clay loam soil under irrigated wheat-soybean rotation. Soil and Tillage Research, 94(2): 386-396.

Blair B J, Lefroy R D B. 1995. Soil carbon fractions based on their degree of oxidation, and the development of a carbon management index for agricultural systems. Australian Journal of Soil Research, 46(7): 1456-1466.

Burges A, Epelde L, Garbisu C. 2015. Impact of repeated single-metal and multi-metal pollution events on soil quality. Chemosphere, 120: 8-15.

Calderón J F, Jackson L E, Scow K M, et al. 2000. Microbial responses to simulated tillage in cultivated and uncultivated soils. Soil Biology and Biochemistry, 32(11-12): 1547-1559.

Chamen W C T, Moxey A P, Towers W, et al. 2015. Mitigating arable soil compaction: A review and analysis of available cost and benefit data. Soil/and Tillage Research, 146: 10-25.

Chang E H, Chung R S, Tsai YH. 2007. Effect of different application rates of organic fertilizer on soil enzyme activity and microbial population. Soil Science and Plant Nutrition, 53(2): 132-140.

Colombo C, Palumbo G, Sannino F, et al. 2002. Chemical and biochemical indicators of managed agricultural soils. In: $17^{\text {th }}$ World Congress of Soil Science. Bangkok, Thailand: WCSS, 1740-1-1740-9.

Drijber R A, Doran J W, Parkhurst A M, et al. 2000. Changes in soil microbial community structure with tillage under long-term wheat-fallow management. Soil Biology and Biochemistry, 32(10): 1419-1430.

Dudal R, Nachtergaele F O, Purnell M F. 2002. The human factor of soil formation. In: Transactions $17^{\text {th }}$ World Congress of Soil Science. Bangkok, Thailand: WCSS, 14-21.

Etana A, Larsbo M, Keller T, et al. 2013. Persistent subsoil compaction and its effects on preferential flow patterns in a loamy till soil. Geoderma, 192: 430-436.

Franco I, Contin M, Bragato G, et al. 2004. Microbiological resilience of soils contaminated with crude oil. Geoderma, 121(1-2): 17-30.

Fu B J, Wang Y F, Lu Y H, et al. 2009. The effects of land-use combinations on soil erosion: a case study in the Loess Plateau of China. Progress in Physical Geography, 33(6): 793-804.

García-Gil J C, Plaza P S, Soler-Rovira P, et al. 2000. Long-term effects of municipal solid waste compost application on soil enzyme activities and microbial biomass. Soil Biology and Biochemistry, 32(13): 1907-1913.

Gary WW, Patrick K. 2006. The impact of soil compaction on soil aeration and fine root density of Quercus palustris. Urban 
Forestry \& Urban Greening, 4(2): 69-74.

Gianfreda L, Rao A M, Piotrowska A, et al. 2005. Soil enzyme activities as affected by anthropogenic alterations: intensive agricultural practices and organic pollution. Science of the Total Environment, 341(1-3): 265-279.

Gregorich E G, McLaughlin N B, Lapen D R, et al. 2014. Soil compaction, both an environmental and agronomic culprit: Increased nitrous oxide emissions and reduced plant nitrogen uptake. Soil Science Society of America Journal, 78(6): 1913-1923.

Gregory A S, Watts C W, Whalley W R, et al. 2007. Physical resilience of soil to field compaction and the interactions with plant growth and microbial community structure. European Journal of Soil Science, 58(6): 1221-1232.

Gómez-Sagasti M, Alkorta I, Becerril J M, et al. 2012. Microbial monitoring of the recovery of soil quality during heavy metal phytoremediation. Water, Air \& Soil Pollution, 223(6): 3249-3262.

Grzesiak M T. 2009. Impact of soil compaction on root architecture, leaf water status, gas exchange and growth of maize and triticale seedlings. Plant Root, 3: 10-16.

Jackson M L. 1967. Soil Chemical Analysis. New Delhi: Prentice-Hall of Indian Pvt. Ltd.

Jiao C Q, Wang Y Q, Liu J, et al. 2009. Spatial-temporal variability of soil hardness and effect of soil hardness on other soil properties in rotary tillage in Guanzhong farmland. Agricultural Research in the Arid Areas, 27(3): 7-12. (in Chinese)

Jones R J A, Spoor G, Thomasson A J. 2003. Vulnerability of subsoil's in Europe to compaction: a preliminary analysis. Soil and Tillage Research, 73(1-2): 131-143.

Kristoffersen A Ø, Riley H. 2005. Effects of soil compaction and moisture regime on the root and shoot growth and phosphorus uptake of barley plants growing on soils with varying phosphorus status. Nutrient Cycling in Agroecosystems, 72(2): 135-146.

Labud V, Garcia C, Hernandez T. 2007. Effect of hydrocarbon pollution on the microbial properties of a sandy and a clay soil. Chemosphere, 66(10): 1863-1871.

Li C L, Xu J B, He Y Q, et al. 2012. Dynamic relationship between biologically active soil organic carbon and aggregate stability in long-term organically fertilized soils. Pedosphere, 22(5): 616-622.

Li F S, Wei C H, Zhang F C, et al. 2010. Water-use efficiency and physiological responses of maize under partial root-zone irrigation. Agricultural Water Management, 97(8): 1156¹164.

Li H, Zhang Y, Zhang C G, et al. 2005. Effect of petroleum-containing wastewater irrigation on bacterial diversities and enzymatic activities in a paddy soil irrigation area. Journal of Environmental Quality, 34(3): 1073-1080.

Liang Q, Chen H Q, Gong Y S, et al. 2012. Effects of 15 years of manure and inorganic fertilizers on soil organic carbon fractions in a wheat-maize system in the North China Plain. Nutrient Cycling in Agroecosystems, 92(1): 21-33.

Liang Y C, Yang Y F, Yang C G, et al. 2003. Soil enzymatic activity and growth of rice and barley as influenced by organic manure in an anthropogenic soil. Geoderma, 115(1-2): 149-160.

Marinari S, Masciandaro G, Ceccanti B, et al. 2000. Influence of organic and mineral fertilisers on soil biological and physical properties. Bioresoruce Technology, 72: 9-17.

Masto R E, Chhonkar P K, Singh D, et al. 2008. Changes in soil quality indicators under long-term sewage irrigation in a sub-tropical environment. Environmental Geology, 56(6): 1237-1243.

Mitchell C C, Westerman R L, Brown J R, et al. 1991. Overview of long-term agronomic research. Agronomy Journal, 83(1): 24-29.

Mooney S J, Nipattasuk W. 2003. Quantification of the effects of soil compaction on water flow using dye tracers and image analysis. Soil Use and Management, 19(4): 356-363.

Nannipieri P, Kandeler E, Ruggiero P. 2002. Enzyme activities and microbiological and biochemcial processes in soil. In: Burns R G, Dick R P. Enzymes in the Environment. New York: Marcel Dekker, 1-33.

Nawaz M F, Bourrié G, Trolard F. 2013. Soil compaction impact and modelling. A review. Agronomy for Sustainable Development, 33(2): 291-309.

Ogle S M, Breidt F J, Eve M D, et al. 2003. Uncertainty in estimating land use and management impacts on soil organic carbon storage for US agricultural lands between 1982 and 1997. Global Change Biology, 9(11): 1521-1542.

Ogle S M, Breidt F J, Paustian K. 2005. Agricultural management impacts on soil organic carbon storage under moist and dry climatic conditions of temperate and tropical regions. Biogeochemistry, 72(1): 87-121.

Rezapour S, Samadi A. 2012. Soil quality response to long-term wastewater irrigation in Inceptisols from a semi-arid environment. Nutrient Cycling in Agroecosystems, 91(3): 269-280.

Schjønning P, Christensen B T, Carstensen B. 1994. Physical and chemical properties of s sandy loam receiving animal manure, mineral fertilizer or no fertilizer for 90 years. European Journal of Soil Science, 45(3): 257-268.

Schroth G, Sinclair F L. 2003. Trees, Crops and Soil Fertility Concepts and Research Methods. London: CABI Publishing, 
77-91.

Shen G P, Lu Y T, Zhou Q X, et al. 2005. Interaction of polycyclic aromatic hydrocarbons and heavy metals on soil enzyme. Chemosphere, 61(8): 1175-1182.

Siggins A, Burton V, Ross C, et al. 2016. Effects of long-term greywater disposal on soil: A case study. Science of the Total Environment, 557-558: 627-635.

Smith O H, Petersen G W, Needelman B A. 2000. Environmental indicators of agroecosystems. Advances in Agronomy, 69: 75-97.

Sun H Y, Wang C X, Wang X D, et al. 2013. Changes in soil organic carbon and its chemical fractions under different tillage practices on loess soils of the Guanzhong Plain in north-west China. Soil Use and Management, 29(3): 344-353.

Szolnoki Z, Farsang A, Puskás I. 2013. Cumulative impacts of human activities on urban garden soils: origin and accumulation of metals. Environmental Pollution, 177: 106-115.

Tabatabai M A, Bremner J M. 1969. Use of $p$-nitrophenol phosphate for assay of soil phosphatase activity. Soil Biology and Biochemistry, 1(4): 301-307.

Tabatabai M A, Bremner J M. 1972. Assay of urease activity in soils. Soil Biology and Biochemistry, 4(4): 479-487.

Tang K L. 2003. China Water and Soil Conservation. Beijing: Science Press, 845. (in Chineśe)

Tobiašová E. 2011. The effect of organic matter on the structure of soils of different land uses. Soil and Tillage Research, 114(2): 183-192.

Twnm E K A, Nii-Annang S. 2015. Impact of soil compaction on bulk density and root biomass of Quercus petraea L. at reclained post-lignite mining site in Lusatia, Germany. Applied and Environmental Soil Science, 2015: 504603.

Verma B C, Datta S P, Rattan R K, et al. 2010. Monitoring changes in soil organic carbon pools, nitrogen, phosphorus, and sulfur under different agricultural management practices in the tropics. Environmental Monitoring and Assessment, 171(1-4): 579-593.

Wang Y F, Fu B J, Lü Y H, et al. 2010. Local-scale spatial variability of soil organic carbon and its stock in the hilly area of the Loess Plateau, China. Quaternary Research, 73(1): 70-76.

Yaalon D H, Yaron B. 1966. Framework for man-made soil changes-an outline of metapedogenesis. Soil Science, 102(4): 272-277.

Zhang C, Liu G B, Xue S, et al. 2013. Soil organic carbon and total nitrogen storage as affected by land use in a small watershed of the Loess Plateau, China. European Journal of Soil Biology, 54: 16-24.

Zhang J, Sui Y H. 2011. Changes of active soil organic carbon under different growing stages of Chinese fir plantation. In: 2011 International Conference on New Technology of Agricultural Engineering (ICAE). Zibo: IEEE, 609-612.

Zhang L H, Xie Z K, Zhao R F, et al. 2012. The impact of land use change on soil organic carbon and labile organic carbon stocks in the Longzhong region of Loess Plateau. Journal of Arid Land, 4(3): 241-250.

Zhou Z C, Zhang X Y, Gan Z T. 2015. Changes in soil organic carbon and nitrogen after 26 years of farmland management on the Loess Plateau of China. Journal of Arid Land, 7(6): 806-813.

Mazzoncini M, Sapkota T B, BàrberiP, et al. 2011. Long-term effect of tillage, nitrogen fertilization and cover crops on soil organic carbon and total nitrogen content. Soil and Tillage Research, 114(2): 165-174.

Zhu X M. 1989. Soil and Agriculture in the Loess Plateau. Beijing: Agricultural Press, 248-253. (in Chinese) 